\title{
Data sharing statements for clinical trials
}

\author{
(ब) $(1) \Theta$ OPEN ACCESS \\ A requirement of the International Committee of Medical Journal Editors
}

\begin{abstract}
Darren B Taichman executive deputy editor, Annals of Internal Medicine, Peush Sahni past president, World Association of Medical Editors, Anja Pinborg scientific editor in chief, Ugeskrift for Laeger, Larry Peiperl chief editor, PLOS Medicine, Christine Laine editor in chief, Annals of Internal Medicine, Astrid James deputy editor Lancet, Sung-Tae Hong editor in chief, Journal of Korean Medical Science, Abraham Haileamlak editor in chief, Ethiopian Journal of Health Sciences, , Laragh Gollogly editor, Bulletin of the World Health Organization, Fiona Godlee editor in chief, The BMJ, Frank A Frizelle editor in chief, New Zealand Medical Journal, Fernando Florenzano editor, Revista Médica de Chile, Jeffrey M Drazen editor in chief, New England Journal of Medicine, Howard Bauchner editor in chief, JAMA and the JAMA Network, Christopher Baethge chief scientific editor, Deutsches Ärzteblatt and Deutsches Ärzteblatt International, Joyce Backus associate director for library operations, National Library of Medicine
\end{abstract}

The International Committee of Medical Journal Editors (ICMJE) believes there is an ethical obligation to responsibly share data generated by interventional clinical trials because trial participants have put themselves at risk. In January 2016 we published a proposal aimed at helping to create an environment in which the sharing of deidentified individual participant data becomes the norm. In response to our request for feedback we received many comments from individuals and groups. ${ }^{1}$ Some applauded the proposals while others expressed disappointment that they did not more quickly create a commitment to data sharing. Many raised valid concerns regarding the feasibility of the proposed requirements, the necessary resources, the real or perceived risks to trial participants, and the need to protect the interests of patients and researchers.

It is encouraging that data sharing is already occurring in some settings. Over the past year, however, we have learnt that the challenges are substantial and the requisite mechanisms are not in place to mandate universal data sharing at this time. Although many issues must be addressed for data sharing to become the norm, we remain committed to this goal.

Therefore, ICMJE will require the following as conditions of consideration for publication of a clinical trial report in our member journals:

1.As of 1 July 2018 manuscripts submitted to ICMJE journals that report the results of clinical trials must contain a data sharing statement as described below.

2.Clinical trials that begin enrolling participants on or after 1 January 2019 must include a data sharing plan in the trial's registration. The ICMJE's policy regarding trial registration is explained at www.icmje.org/ recommendations/browse/publishing-and-editorial-issues/ clinical-trial-registration.html. If the data sharing plan changes after registration this should be reflected in the statement submitted and published with the manuscript, and updated in the registry record.

Data sharing statements must indicate the following: whether individual deidentified participant data (including data dictionaries) will be shared; what data in particular will be shared; whether additional, related documents will be available (study protocol, statistical analysis plan, etc); when the data will become available and for how long; by what access criteria data will be shared (including with whom, for what types of analyses, and by what mechanism). Illustrative examples of data sharing statements that would meet these requirements are in the table.

These initial requirements do not yet mandate data sharing, but investigators should be aware that editors may take into consideration data sharing statements when making editorial decisions. These minimum requirements are intended to move the research enterprise closer to fulfilling our ethical obligation to participants. Some ICMJE member journals already maintain, or may choose to adopt, more stringent requirements for data sharing.

Sharing clinical trial data is one step in the process articulated by the World Health Organization (WHO) and other professional organisations as best practice for clinical trials: universal prospective registration; public disclosure of results from all clinical trials (including through journal publication); and data sharing. Although universal compliance with the requirement to prospectively register clinical trials has not yet been achieved and requires continued emphasis, we must work towards fulfilling the other steps of best practice as well- including data sharing.

As we move forward into this new norm where data are shared, greater understanding and collaboration among funders, ethics committees, journals, trialists, data analysts, participants, and others will be required. We are currently working with members of the research community to facilitate practical solutions to enable data sharing. The US Office for Human Research 
Protections has indicated that provided the appropriate conditions are met by those receiving them, the sharing of deidentified individual participant data from clinical trials does not require separate consent from trial participants. ${ }^{2}$ Specific elements to enable data sharing statements that meet these requirements have been adopted at ClinicalTrials.gov (https:// prsinfo.clinicaltrials.gov/definitions.html\#shareData). WHO also supports the addition of such elements at the primary registries of the International Clinical Trials Registry Platform. Unresolved issues remain, including appropriate scholarly credit to those who share data, and the resources needed for data access, the transparent processing of data requests, and data archiving. We welcome creative solutions to these problems at www.icmje.org.

We envision a global research community in which sharing deidentified data becomes the norm. Working towards this vision will help maximise the knowledge gained from the efforts and sacrifices of clinical trial participants.

This article is being published simultaneously in Annals of Internal Medicine, The BMJ, Bulletin of the World Health Organization, Deutsches Ärzteblatt, Ethiopian Journal of Health Sciences, JAMA, Journal of Korean Medical Science, New England Journal of Medicine, New
Zealand Medical Journal, PLOS Medicine, Lancet, Revista Médica de Chile, and Ugeskrift for Laeger. PS's affiliation with the World Association of Medical Editors does not imply endorsement by WAME member journals that are not part of the ICMJE.

Competing interests: We have read and understood BMJ policy on declaration of interests and declare that LP has received travel reimbursement from the WHO and the Association of Health Care Journalists for consulting and speaking activities relating to data sharing. Provenance and peer review: Commissioned; not externally peer reviewed.

1 Taichman DB, Backus J, Baethge C, et al. Sharing clinical trial data: a proposal from the International Committee of Medical Journal Editors. Ann Intern Med 2016;357:505-6.doi: 10.7326/M15-2928 pmid:26792258

2 Menikoff J. Letter from Jerry Menikoff, MD, JD, director, Office for Human Research Protections, to ICMJE secretariat. 7 March 2017. http://icmje.org/news-and-editorials/ menikoff_icmje_questions_20170307.pdf

Published by the BMJ Publishing Group Limited. For permission to use (where not already granted under a licence) please go to http://group.bmj.com/group/rights-licensing/ permissions

This is an Open Access article distributed in accordance with the Creative Commons Attribution Non Commercial (CC BY-NC 4.0) license, which permits others to distribute, remix, adapt, build upon this work non-commercially, and license their derivative works on different terms, provided the original work is properly cited and the use is non-commercial. See: http://creativecommons.org/licenses/by-nc/4.0/. 


\section{Table}

\begin{tabular}{|c|c|c|c|c|}
\hline & Example 1 & Example 2 & Example 3 & Example 4 \\
\hline $\begin{array}{l}\text { Will individual participant } \\
\text { data be available (including } \\
\text { data dictionaries)? }\end{array}$ & Yes & Yes & Yes & No \\
\hline $\begin{array}{l}\text { What data in particular will } \\
\text { be shared? }\end{array}$ & $\begin{array}{l}\text { All of the individual participant } \\
\text { data collected during the trial, } \\
\text { after deidentification }\end{array}$ & $\begin{array}{l}\text { Individual participant data that underlie } \\
\text { the results reported in this article, after } \\
\text { deidentification (text, tables, figures, } \\
\text { and appendices) }\end{array}$ & $\begin{array}{l}\text { Individual participant data that underlie the } \\
\text { results reported in this article, after } \\
\text { deidentification (text, tables, figures and } \\
\text { appendices) }\end{array}$ & Not available \\
\hline $\begin{array}{l}\text { What other documents will } \\
\text { be available? }\end{array}$ & $\begin{array}{l}\text { Study protocol, statistical } \\
\text { analysis plan, informed } \\
\text { consent form, clinical study } \\
\text { report, analytic code }\end{array}$ & $\begin{array}{l}\text { Study protocol, statistical analysis plan, } \\
\text { analytic code }\end{array}$ & Study protocol & Not available \\
\hline $\begin{array}{l}\text { When will data be available } \\
\text { (start and end dates)? }\end{array}$ & $\begin{array}{l}\text { Immediately after publication. } \\
\text { No end date }\end{array}$ & $\begin{array}{l}\text { Beginning } 3 \text { months and ending } 5 \\
\text { years after article publication }\end{array}$ & $\begin{array}{l}\text { Beginning } 9 \text { months and ending } 36 \text { months } \\
\text { after article publication }\end{array}$ & Not applicable \\
\hline With whom? & $\begin{array}{l}\text { Anyone who wishes to access } \\
\text { the data }\end{array}$ & $\begin{array}{l}\text { Researchers who provide a } \\
\text { methodologically sound proposal }\end{array}$ & $\begin{array}{l}\text { Investigators whose proposed use of the } \\
\text { data has been approved by an independent } \\
\text { review committee ("learned intermediary") } \\
\text { identified for this purpose }\end{array}$ & Not applicable \\
\hline $\begin{array}{l}\text { For what types of } \\
\text { analyses? }\end{array}$ & Any purpose & $\begin{array}{l}\text { To achieve aims in the approved } \\
\text { proposal }\end{array}$ & For individual participant data meta-analysis & Not applicable \\
\hline \multirow[t]{2}{*}{$\begin{array}{l}\text { By what mechanism will } \\
\text { data be made available? }\end{array}$} & \multirow[t]{2}{*}{$\begin{array}{l}\text { Data are available indefinitely } \\
\text { at (Link to be included). }\end{array}$} & $\begin{array}{l}\text { Proposals should be directed to } \\
\text { xxx@yyy. To gain access, data } \\
\text { requestors will need to sign a data } \\
\text { access agreement. }\end{array}$ & $\begin{array}{l}\text { Proposals may be submitted up to } 36 \text { months } \\
\text { following article publication. After } 36 \text { months } \\
\text { the data will be available in our university's } \\
\text { data warehouse but without investigator } \\
\text { support other than deposited metadata. }\end{array}$ & \multirow[t]{2}{*}{ Not applicable } \\
\hline & & $\begin{array}{l}\text { Data are available for } 5 \text { years at a third } \\
\text { party website. (Link to be included) }\end{array}$ & $\begin{array}{l}\text { Information regarding submitting proposals } \\
\text { and accessing data may be found at (Link } \\
\text { to be provided). }\end{array}$ & \\
\hline
\end{tabular}

